\title{
ENAT Karacabey endüstriyel ağaçlandırma yatırımında hasılat ve iç karlılık analizi
}

\author{
Yield and internal rate of return analysis for Karacabey industrial afforestation \\ investment
}

\author{
Neşat ERKAN ${ }^{1}$ \\ Kenan $\mathrm{OK}^{2}$ \\ Salih PARLAK ${ }^{1}$
}
' Bursa Teknik Üniversitesi, Orman Fakül- tesi, Bursa
${ }^{2}$ İstanbul Üniversitesi -Cerrahpaşa, Orman Fakültesi, İstanbul

\begin{abstract}
Sorumlu yazar (Corresponding author) Neşat ERKAN

nesaterkan@yahoo.com
\end{abstract}

Geliş tarihi (Received)

06.09.2019

Kabul Tarihi (Accepted)

06.11.2019

\section{Öz}

Ülkemizde orman endüstrisinin ihtiyaç duyduğu odun ham maddesinin karşılanması konusu, uzun yıllardır gündemdeki önemini korumaktadır. Özellikle özel sektör tarafından yapılacak endüstriyel ağaçlandırma yatırımlarında, girişimin ekonomik sonuçlarının ne olacağ1 ve kurulan plantasyonların hangi idare süresiyle işletilmesi gerektiği konularının, bilimsel çalışmalarla ortaya konması gerekmiştir. Bu çalışmada, Endüstriyel Ağaç Tarımı Sanayi ve Ticaret A. Ş. (ENAT) tarafından Bursa-Karacabey'de Sahilçamı ile yapılmış 493 ha büyüklüğündeki ağaçlandırma sahası örnek alınarak değerlendirilmiştir. Çalışma, ağaçlandırma alanının değişik bölgelerinden alınan 15 adet deneme sahasındaki tek ağaca dayalı gövde analizleri ve alan bazında yapılan hasılat ölçmeleri temel alınarak yapılmıştır. Ekonomik analizler için İç Karlılık Oranı Kriteri kullanılmıştır. Elde edilen sonuçlar, Karacabey Sahilçamı ağaçlandırma alanının beşli sınıflamaya göre I. ve II. bonitet alanlarından oluştuğunu, çoğunluğu 12 yaşında olan sahada bu yaşta ortalama artımın $20 \mathrm{~m}^{3} / \mathrm{y} 1 \mathrm{l}$ a kadar çıkabildiğini göstermiştir. Yapılan iç karlılık analiz sonuçları, değişik arazi edinme ve kullanım stratejilerine göre değişmekle birlikte, yatırım sahasında hesaplanan iç karlılık oranlarının \%12,263'e kadar ulaştığını göstermektedir. Özellikle kullanılma olasılığı en yüksek strateji olan tahsisli araziler Sahilçamı ile ağaçlandırma yapılmas1 durumunda iç karlılık oranının 16 yıl idare süresi için \%11,183'e kadar yükseldiği gözlenmiştir. Diğer önemli bir bulgu ise, analizi yapılan 6 değişik stratejiden 5'i için, iç karlılık oranına göre idare süresinin 15 ve 16 yıl olmasıdır.

Anahtar Kelimeler: Sahil çamı, İdare süresi, Odun hammaddesi, Odun arz açı̆̆ 1

\begin{abstract}
Supply deficit of timber raw material needed by Turkish forest industry has been one of the important issues discussed for years. However, certain issues such as length of rotation period and economic result of the plantation need to be cleared, notably for private sector. With this study, Bursa-Karacabey plantation, which were established by Industrial Tree Farming Commercial Anonym Company (ENAT) using Pinus pinaster Ait. in 493 hectare area was evaluated as case study. Study was based on the stem and stand growth analyses and measurement in 15 sample plots taken from study area. Internal Rate of Return (IRR) was used for economic analyses. Results showed that the area was good sites (I. and II. class for the five classification) for $P$. pinaster and mean annual growth per hectare can reach up to 20 $\mathrm{m}^{3}$ in good sites at 12 years old. IRR's were calculated up to $12,263 \%$, however, it changed depending on length of rotation period and 6 land ownership options. IRR was calculated as $11,183 \%$ for the option of 16 years of rotation period and the lands allocated by state to companies for afforestation, which is common way for land supply system used by private companies. Additionally, we found that length of rotation periods determined using IRR were 15-16 years for 5 different land supply options with an exception.
\end{abstract}

Key words: Pinus pinaster (Ait.), rotation period, wood production, wood supply deficit. 


\section{Giriş}

Cumhuriyetin ilk yıllarından beri, ülkenin ihtiyaç duyduğu odun hammaddesinin nasıl karşılanabileceği sorunu, ülke ekonomisinin ve ormancılık kurumlarının önemli bir problemi olmuștur. Orman endüstri kuruluşlarının kurulu kapasitelerinin zamanla gelişmesiyle birlikte, hammadde tedarik sorunu önemini düşürmeden gündemdeki yerini korumuştur. Bugün, orman endüstrisinden, orman kaynakları yöneticisine, kısaca tüm sektörün ilgilendiği bir odun hammaddesi arz açığı sorunu bulunmaktadır.

Türkiye'de odun hammaddesi işleyen endüstri kuruluşlarının talep yapısı zamanla değişimler gösterse de, her geçen gün talep miktarı yükselmiştir. Tek üretici konumda olan Orman Genel Müdürlüğü'nün (OGM) endüstriyel odun üretimi de zamanla artmıştır. Örneğin 2013 yılında 13.668 .000 $\mathrm{m}^{3}$ olan endüstriyel odun üretimi, 2018 yılında $19.080 .000 \mathrm{~m}^{3}$ e ulaşmıştır (URL 1). Yurt içi üretimdeki artışın etkisiyle ithal edilen endüstriyel odun miktarında bir düşme eğilimi görülmüşse de, Türkiye halen odun hammaddesi arz açığını önleyebilmiş değildir. Örneğin 2018 yılında 1.108 .000 $\mathrm{m}^{3}$ odun ithalatı gerçekleşmiştir (OGM, 2019). Kağıt hamuru üretiminin ithal hamura dayalı bir hal alması, arz açığını giderecek gibi gürünmüşse de, Türkiye 2010 yılında odun kökenli levha üretiminde Dünya'nın dokuzuncu büyük ülkesi (İlter ve Ok, 2012) haline gelmiş ve hammadde talep artış1 sürmüştür. Halen başta lif yonga sanayi olmak üzere, kereste, kâğıt ve ambalaj sanayi için gerekli hammadde ihtiyacının yaklaşık \% 80'i devlet ormanlarından ve Orman Genel Müdürlüğü tarafından karşılanabilmektedir (TOD, 2019). Dış alımda kullanılması zorunlu olan döviz kurunun istikrarsızlığı, orman endüstrisinin istikrarlı stratejiler geliştirmesini güçleştirmekte, ülke içi üretimin artırılmasını zorunlu kılmaktadır.

Yerli ve ithal hızlı büyüyen ağaç türleri kullanarak yapılacak ağaçlandırma yatırımları ile Ülkemizdeki orman endüstri kuruluşlarının odun ihtiyacının karşılanması düşüncesi 50 yılı aşkın süredir üzerinde durulan konulardandır (Eraslan, 1983). Bu kapsamda çok sayıda ithal ağaç türü denenerek adaptasyon kabiliyetleri ve büyüme performansları denenmiştir (Tunçtaner, 2007). Bu denemeler sonucunda Marmara bölgesi için başarılı bulunup ağaçlandırılması önerilen türlerden birisi de Sahilçamı (Pinus pinaster Ait.) olmuştur (Tunçtaner ve ark., 1988; Birler, 2009).

Yapılan deneme sonuçlarından elde edilen bilgilere dayanarak bazı ağaçlandırma çalışmaları yapılmış olmakla birlikte, bu konuda atılmış en önemli adım, OGM tarafından iyi bonitetli yerlerde yoğun silvikültürel yöntemleri de kullanarak, endüstriyel odun üretimine yönelik bir ağaçlandırma programının başlatılması olmuştur. Bu program kapsamında, 2013-2017 dönemi için "Endüstriyel Ağaçlandırma Çalışmaları Eylem Planı” hazırlanarak uygulamaya konmuştur (OGM, 2013). Plan kapsamında, önce özellikleri bakımından; iyi bonitetli (I. ve II. bonitet), eğimi \% 30'dan düşük, edafik ve fizyolojik şartları uygun ve en az 5 ha büyüklügünndeki alanlar potansiyel alan olarak belirlenmişse de, daha sonra yapılan bir değişiklikle, eğim sınırı \% 50'ye çıkartılmıştır. Eylem planında, ağaçlandırma için kullanılması öngörülen ağaç türlerine bakıldığında, Sahilçamı yabancı tür olarak öne çıkmaktadır.

Endüstriyel ağaçlandırmayı geleneksel ağaçlandırmalar ile karıştırmamak gereklidir. Endüstriyel ağaçlandırmalar; "iyi bonitetli yerlerde, yoğun toprak hazırlama ve bakım tedbirleri uygulayarak ve genetik olarak sslah edilmiş yüksek verim gücünde ağaç türleri kullanılarak kısa idare süresi ile kurulan ağaçlandırmalar" olarak tanımlanmaktadır (Birler, 2009). Özellikle seksenli yıllar sonrasında, özel sektörün de, endüstriyel ağaçlandırmalara yatırım yapması pek çok ortamda dile getirilmiş ve çeşitli şekillerde teşvik edilmiştir. Bu kapsamda düşünülebilecek bir endüstriyel ağaçlandırmaya, aralarında sanayicilerin, orman endüstri kuruluşu ortaklarının da bulunduğu 26 özel girişimci ilgi göstermiş ve 2005 yılında bu girişimcilerin kurucu ortaklığında, Endüstriyel Ağaç Tarımı Sanayi ve Ticaret A.Ş. (ENAT) kurulmuştur.

Ön hasılat ve ekonomik analizlerin "yapılabilir" olma yönünde işaretler vermesiyle birlikte, 2005 yılından itibaren ENAT satın aldığı kendi arazileri ile bozuk orman alanlarından tahsis edilmiş devlet arazisinde hızlı büyüyen, Sahilçamı ve Kızılçam (Pinus brutia Ten.) türleriyle ağaçlandırma yatırımları yapmaya başlamıştır.

Endüstriyel ağaçlandırmalar gerek ekonomik anlamda birer yatırım niteliği taşımaları ve gerekse endüstri kuruluşlarının kendi hammadde ihtiyaçlarını karşılamaları nedeniyle özel ağaçlandırmalara da konu olmaktadır. Türkiye'de özel ağaçlandırmalar zaman zaman hızlanan zaman zaman yavaşlayan teşvik ve ilgiyle karşılaşmıştır. Bu konuda son olarak, 12/03/2013 tarih ve 6912 numara ile OGM tarafindan yayınlanan Özel Ağaçlandırma Tamiminde, endüstriyel ağaçlandırmaları da kapsayan özel ağaçlandırma çalışmalarının devlet ormanlarından ve hazine arazilerinden özel veya tüzel kişilere tahsis edilecek alanlarda veya tapulu alanlarda yapılış şekli düzenlenmiştir (URL 2). Ayrıca tamimde, 
kullanılabilecek türler listesinde, Sahilçamını da kapsayan "çam" türleri de yer almış ve söz konusu ağaçlandırmalar için verilecek hibe veya kredi desteği ve bunun koşulları belirlenmiştir.

Türkiye'de özel sektörün ağaçlandırma yatırımlarına uzun yıllar girmeme sorunu, genellikle farkındalık artırarak aşılmaya çalışılmıştır. Proje hazırlamaya yardım, fidan desteği, arazi tahsisi gibi teşvik araçları oluşturulmuşsa da, bu alana yatırım yapılmamasının kökeninde, yapılan yatırımın girişimciye kazandıracağı ekonomik getirinin düşük veya belirsiz görülmesine yönelik kaygılar bulunmaktadır. Nitekim ENAT deneyiminden önce, Türkiye'de pek çok özel kişi ve kurum ağaçlandırma yapmışsa da teknik analizlere dayalı ve "ticari beklentilerle" yapılmış bir ağaçlandırma çalışmasının bulunduğunu söylemek güçtür.

Buna karşı1ık, orman ağaçlarına göre daha kısa idare süreli dikimlere olanak veren Kavak çeşitlerinde daha iyi bir sonuç alınmıştır. Pek çok Kavak yatırım deneyiminin yaşanmış olması, bu ağaçlandırmalar üzerine yapılmış Birler ve Ark. (1989), Diner ve Koçer (1999), Koçer (1999) örneklerinde görüldüğü gibi, bilimsel temelli ekonomik analizlerle karlılığın kanıtlanması, kavakçılık girişimlerinin yaygınlaşmasına destek olmuştur. Yatırımcılar, yapacakları yatırımın gerektirdiği uzun idare süresinin sonunda elde edeceği odun hasılatının miktarını, o dönemde oluşabilecek piyasa fiyatlarını, farklı zamanlarda katlandığı giderler ile elde ettiği gelirlerin "sonuç olarak nasıl bir ekonomik" anlam ifade ettiğini bilmediğinden, diğer hızlı gelişen türlere dayalı ağaçlandırma girişimde bulunmakta tereddüt etmiştir.

Gerçekten de, ağaçlandırma yatırımlarında sermaye, işin doğası gereği uzun bir süre yatırıma bağlanmaktadır. Yatırım ilk yıl yapılmış gibi görünse de, üretim dönemi içerisinde bakım ve koruma giderlerine katlanılmakta, yapılan hasat, ayrıca masraf gerektirmektedir. Her ne kadar, yapılacak aralamalarla, ara hasılat ve sonuçta son hasılat elde edileceği bilinse de, bu hasılat miktarlarının ilgilenilen alan için ne miktarda olduğu, bağlanan sermayenin ne kadarının geri alınabildiği, hangi düzeyde kar elde edileceği de belli doğrulukta bilinmelidir. Bu noktada, ağaçlandırma yatırımı ile elde edilecek tüm hasılat ve gelirleri ile yapılacak masrafları, bunların zaman değerlerini de dikkate alarak bir ekonomik analize gereksinim vardır. Girişimciler, ne yazık ki bu analizleri yapma ve yorumlama noktalarında tatmin edilememiş ve endüstriyel ağaçlandırmalara girişleri yaygınlaştırılamamıştır.

Türkiye'de ağaçlandırma yatırımlarının ekonomik analizi konusunda, esasen uzun bir geçmişe dayalı birikim (Dow ve Shaw 1966, Birler ve Ark. 1989, Diner ve Koçer 1999, Koçer 1999, Daşdemir ve Şahin 2002 örneklerinde görüldüğü gibi) bulunmaktadır. Özellikle kavakçılık alanında başarılı ekonomik analizler yapılmıştır. Bununla birlikte, ekonomik analizleri başarıyla yapabilmek için sadece uygun ekonomik yöntemleri bilmek, başarıyla

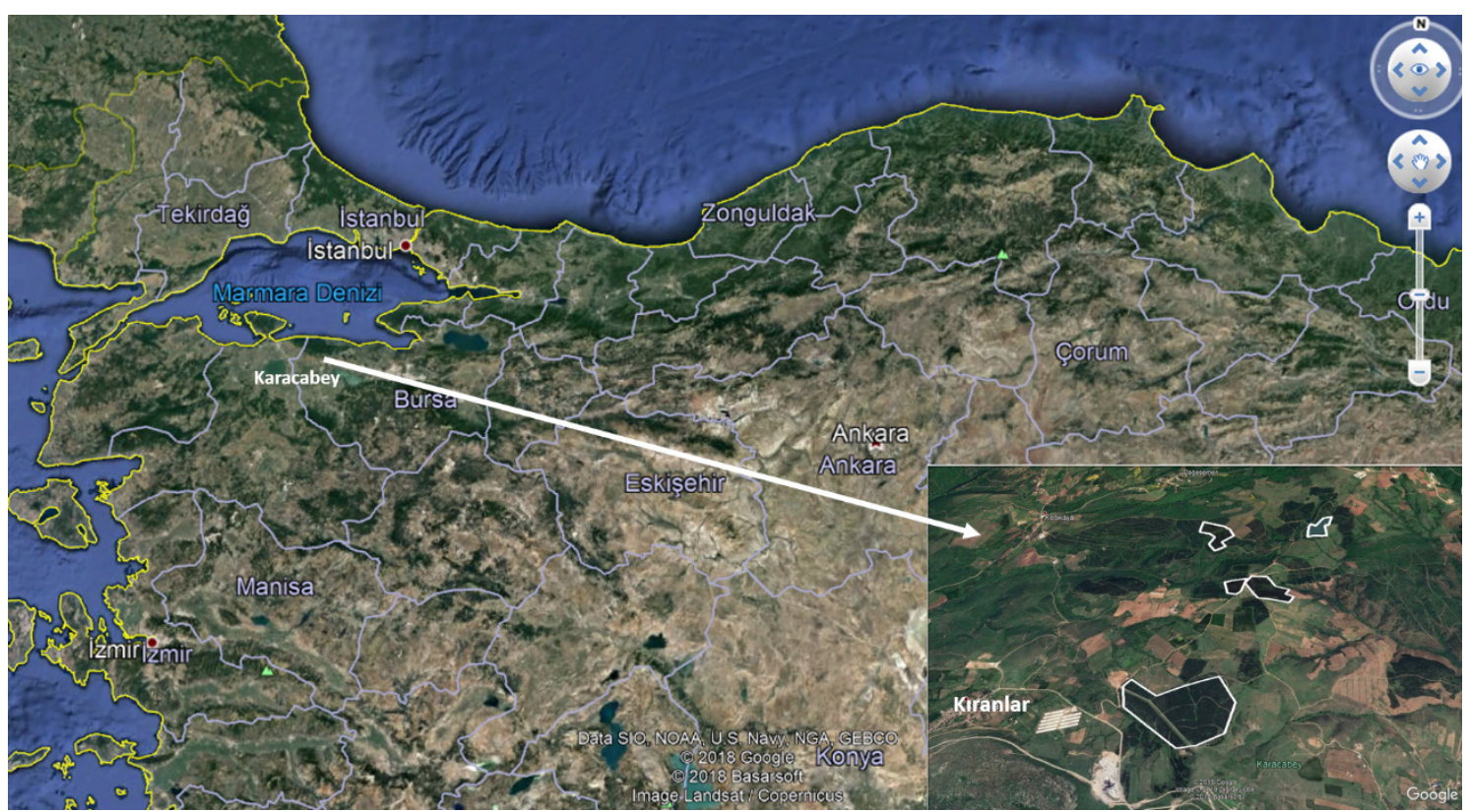

Şekil 1. Deneme alanlarının alındığı ENAT-Karacabey ağaçlandırma alanları

Figure 1. Location of Samplings on Afforestation Areas Planted by ENAT 
uygulamak yeterli değildir. Öncelikle, analizlerin gerektirdiği hasılat verilerinin yatırımın yapılacağ yer özelinde ölçülmesi veya yeteri doğrulukta tahmin edilebilmesi gereklidir.

$\mathrm{Bu}$ anlamda, ENAT tarafından 2005 yılından başlayarak Sahilçamı ile yapılan ağaçlandırma alanlarında hasılat bilgileri ile yapılan masraflara ve gelirlere ilişkin bilgi edinilebilecek bir ortam oluşmuş, deneyim gerçekleşmiştir. Bir başka değişle, bu yatırımdan yola çıkarak, başkaca endüstriyel ağaçlandırma yatırımlarına fikir verebilecek ekonomik analizlerin yapılabilmesi mümkün hale gelmiştir. Bu nedenle çalışmada, ENAT tarafından yapılan ağaçlandırma yatırımlarından birisi olan Bursa, Karacabey endüstriyel ağaçlandırma sahası ele alınarak, öncelikle hasılat bulgularının ortaya konması, ardından bu bulguların ekonomik analizini yaparak, olası yatırımcılara, fiili verilere ve deneyime dayalı bir fikrin verilmesi, benzer yatırımları teşvik edecek araçların etkinliklerinin tartışılması amaçlanmıştır.

\section{Materyal ve Metot}

Çalışma ENAT tarafından Bursa-Karacabey'de Sahilçamı fidanı kullanılarak tesis edilen, 120 ha tapulu, 373 ha bozuk orman arazilerinden tahsisli olmak üzere, toplam 493 ha ağaçlandırma sahasından elde edilen verilerle yapılmıştır. Çalışmanın yapıldı̆̆ 1 alanlar ve deneme alanı yerleri Şekil 1'deki haritada işaretlenmiş, deneme alanlarına ilişkin özellikler ise Tablo 1'de verilmiştir. Deneme alanlarındaki ölçme ve tespitler 2018 yılı vejetasyon sonunda yapılmıştır.

Deneme alanları 2005 ve 2006 yıllarında başlayarak yapılan ağaçlandırma alanları içinden alınmıştır. Ağaçlandırma, Sındırgı Orman Fidanlığında yetiştirilen $1+0$ yaşlı fidanlardan satın alınarak yapılmıştır. Dikimde çoğunlukla 3x1,5 m aralık mesafe kullanılmış ancak ağaçlandırma alanının bazı yerlerinde bu aralık mesafeler değişmiş, zaman içinde ölen ağaçlar nedeniyle sıklığın değişebildiği görülmüştür.

Tablo 1. Deneme alanlarına ilişkin özellikler

Table 1. Some Characteristics of Sampling Areas

\begin{tabular}{|c|c|c|c|c|}
\hline $\begin{array}{l}\text { Deneme } \\
\text { Alan No }\end{array}$ & Koordinatlar & $\begin{array}{l}\text { Yükselti } \\
\text { (m) }\end{array}$ & $\begin{array}{c}\text { Bonitet Endeksi } \\
(\mathrm{m})^{*}\end{array}$ & Bonitet Derecesi* \\
\hline 1 & $40^{\circ} 16^{\prime} 23^{\prime \prime} \mathrm{N}, 28^{\circ} 20^{\prime} 06^{\prime \prime} \mathrm{E}$ & 283 & 17,2 & I \\
\hline 2 & $40^{\circ} 16^{\prime} 23^{\prime \prime} \mathrm{N}, 28^{\circ} 20^{\prime} 07^{\prime \prime} \mathrm{E}$ & 290 & 15,7 & II \\
\hline 3 & $40^{\circ} 16^{\prime} 23^{\prime \prime} \mathrm{N}, 28^{\circ} 20^{\prime} 07^{\prime \prime} \mathrm{E}$ & 291 & 16,1 & II \\
\hline 4 & $40^{\circ} 16^{\prime} 56^{\prime \prime} \mathrm{N}, 28^{\circ} 20^{\prime} 35^{\prime \prime} \mathrm{E}$ & 260 & 16,5 & II \\
\hline 5 & $40^{\circ} 17^{\prime} 00^{\prime \prime} \mathrm{N}, 28^{\circ} 20^{\prime} 38^{\prime \prime} \mathrm{E}$ & 262 & 16,3 & II \\
\hline 6 & $40^{\circ} 17^{\prime} 00^{\prime \prime} \mathrm{N}, 28^{\circ} 20^{\prime} 42^{\prime \prime} \mathrm{E}$ & 261 & 14,3 & II \\
\hline 7 & $40^{\circ} 16^{\prime} 55^{\prime \prime} \mathrm{N}, 28^{\circ} 20^{\prime} 46^{\prime \prime} \mathrm{E}$ & 265 & 17,2 & I \\
\hline 8 & $40^{\circ} 16^{\prime} 52^{\prime \prime} \mathrm{N}, 28^{\circ} 20^{\prime} 44^{\prime \prime} \mathrm{E}$ & 271 & 15,7 & II \\
\hline 9 & $40^{\circ} 17^{\prime} 24^{\prime \prime} \mathrm{N}, 28^{\circ} 21^{\prime} 08^{\prime \prime} \mathrm{E}$ & 316 & 16,6 & I \\
\hline 10 & $40^{\circ} 17^{\prime} 27^{\prime \prime} \mathrm{N}, 28^{\circ} 21^{\prime} 14^{\prime \prime} \mathrm{E}$ & 332 & 17,2 & I \\
\hline 11 & $40^{\circ} 17^{\prime} 28^{\prime \prime} \mathrm{N}, 28^{\circ} 20^{\prime} 59^{\prime \prime} \mathrm{E}$ & 321 & 16,6 & I \\
\hline 12 & $40^{\circ} 17^{\prime} 22^{\prime \prime} \mathrm{N}, 28^{\circ} 20^{\prime} 35^{\prime \prime} \mathrm{E}$ & 300 & 15,4 & II \\
\hline 13 & $40^{\circ} 17^{\prime} 26^{\prime \prime} \mathrm{N}, 28^{\circ} 20^{\prime} 30^{\prime \prime} \mathrm{E}$ & 298 & 16,5 & II \\
\hline 14 & $40^{\circ} 17^{\prime} 21^{\prime \prime} \mathrm{N}, 28^{\circ} 21^{\prime} 08^{\prime \prime} \mathrm{E}$ & 305 & 15,7 & II \\
\hline 15 & $40^{\circ} 17^{\prime} 00^{\prime \prime} \mathrm{N}, 28^{\circ} 20^{\prime} 38^{\prime \prime} \mathrm{E}$ & 261 & 22,6 & I \\
\hline
\end{tabular}

*: Özcan (2003) tarafından düzenlenen 5 li bonitet tablosu temel alınmıştır.

Hasılat araştırması için gerekli ölçmeler $15 \times 20 \mathrm{~m}$ boyutlarındaki deneme alanlarında yapılmıştır. Deneme alanlarında yapılan ölçmelerle elde edilen hasılat değerleri, 10000/300 katsayısı ile çarpılarak hektara çevrilmiştir. Her bir deneme alanında meşcereyi temsil edecek nitelikte, meşcere orta ağac1 çapına karşılık gelen bir ağaçta gövde analizi yapılmıştır.
Ağaç göğüs çaplarının ölçülmesinde $50 \mathrm{~cm}$ kapasiteli, mm duyarlıklı çap ölçer, ağaç boyunun ölçümünde ise BLUME-LEISS boy ölçer kullanılmıştır. Deneme alanındaki ağaçları hacimlendirirken, Özcan (2003) tarafından hazırlanan ve Formül 1'de verilen, çift girişli ağaç hacim denklemi kullanılmiştır. 
$\ln (v)=-10,0172+1,673353 * \ln (d)+1,323705 * \ln \left(\frac{h_{2}}{(h-1,3)}\right)$

(1)

Formül 1'de; $v$ : ağaç gövde hacmini $\left(\mathrm{dm}^{3}\right), d$ : göğüs çapını (cm), $h$ : ağaç boyunu (m) ifade etmektedir.

Deneme alanındaki ağaçların çap, boy ve hacim gelişimlerinin izlenmesi amacıyla gövde analizi yapılmıştır. Bu amaçla deneme alanını temsil etmesi bakımından göğüs yüzeyi orta ağacına karşılık gelen bir ağaç seçilerek gövde analizine konu edilmiştir.

Deneme alanlarından elde edilen hektardaki toplam hacimler yaşa bölünerek yıllık genel ortalama hacim artımı (GOA) bulunmuştur. Deneme alanlarından 12. yaş için hesaplanan GOA'ların diğer yaşlardaki değişimini bulmak için, Özcan'ın (2003) hasılat tablosundan yararlanılmıştır. Bunun için 15 deneme alanından hesaplanan GOA'ların ortalaması baz alınarak hasılat tablosunda enterpolasyon yöntemiyle 12 yaș için karşılığı bulunmuş ve tablodan diğer yaşlar için GOA'lar aynı yöntemle hesaplanmıştır. Benzer şekilde GOA'lar ilgili yaşlarla çarpılarak değişik yaşlardaki ağaç servetleri hektardaki değerleri cinsinden hesaplanmıştır.

Ekonomik analizler için 10 ve 20 yaşlarında ayrılan meşcere hacmi kadar hasılatın aralama hasılası olarak alınacağı varsayılmıştır. 10 yaşında yapılan aralamada çıkartılan hacim miktarı deneme alanlarından tespit edilen miktarın ortalaması şeklinde alınmıştır. Her bir deneme alanında çıkartılan hacim miktarı ise ilgili deneme alanında gövde analizi yapılan ağaç hacminin, yapılan fiili aralama ile çıkartılan ağaç sayısıyla çarpımı ile hesaplanmıştır. 20 yaşında yapılacak aralama ile çıkartılacak hacim miktarının hesabında ise, fiili bir aralama durumu söz konusu olmadığından, hasılat tablosundan yararlanılmıştır. Hasılat tablosunun 20 yaşındaki ara hasılat değeri aralama ile elde edilecek hasılat olarak kabul edilmiştir. Hangi bonitette bir hasılat tablosunu kullanmak gerektiğini kararlaştırırken, yukarda açıklanan ve GOA' ların hesabında benimsenen yol izlenmiştir. Bir başka değişle, 12. yaştaki deneme alanlarının GOA' larının hasılat tablosundaki karşılığı (enterpolasyon yöntemiyle belirlenmiş) dikkate alınarak, ayrılan meşcere hacmi aralama ile çıkartılacak hacim olarak alınmıştır.

Bir yatırımın ekonomik analizini, ülke ve girişimcinin ekonomisini temel alarak iki ayrı yaklaşımla yapmak mümkündür. Yatırımın ülke ekonomisine etkilerinin analiz edilmesine "ulusal karlılık analizi" ismi verilirken, girişimci açısından yapılan değerlendirmeye "ticari karlılık analizi” denmektedir (İlter, 2001). Ulusal karlılık analizinde; sermaye hasıla oranı, sermaye istihdam oranı, ulusal fayda maliyet oranı, katma değer, dış ödemeler dengesine etki, vb. ölçütler kullanılırken, Ticari karlılık analizinde; basit karlılık oranı, geri ödeme süresi, net bugünkü değer (NBD), ticari fayda maliyet oranı ve iç karlılık oranı (İKO) kriterlerine (Balçık, 2003) başvurulmaktadır. Bu analizlerle, bir yatırım için gerekli sermaye veya nakdin, proje veya diğer kaynaklarla karşılanıp karşılanmadığını etüt eden finansal analizleri veya likidite analizlerini aynı kabul etmek olanaklı değildir. Şüphesiz ekonomik açıdan yapılabilir bir yatırımın finansal açıdan da yapılabilir olması beklenir. Ancak bu çalışmada, incelenen örnek olayın ticari bir girişim olduğu dikkate alınarak, ticari karlılık analiziyle sınırlı kalmak gerektiğine karar verilmiştir.

Ticari karlılık analizinde kullanılan, basit karlılık oranı, geri ödeme süresi, NBD ve ticari fayda maliyet oranı ölçütleri yerine, araştırmanın sadece İKO ölçütüne odaklanması yeterli bulunmuştur. Bilindiği gibi, basit karlılık oranı ölçütünün, çok yıllık yatırımları hesaplayabilme zafiyeti bulunmaktadır. Geri ödeme süresi ise yatırım projesinin sadece yatırım tutarını geri ödeyebildiği süreye odaklanmakta ve girişimcinin yatırımın tüm ömrünü dikkate alabilmesini engellemektedir. NBD ölçütünde ise, bir yandan hangi iskonto oranının kullanılması gerektiğine yönelik dışsal kararlar almak gerekirken, diğer yandan "farklı yatırım seçeneklerini karşılaştırırken” ölçeğin değişip değişmediği noktasında tartışılır sonuçlar üretmektedir. Fayda maliyet oranı da, iskonto oranı konusunda NBD ölçütüyle benzer sorunlara sahiptir. Koçer (1999), de ağaçlandırma projelerinin değerlendirilmesinde İKO ölçütünün kullanılmasının daha uygun ve yeterli olacağını ifade etmiştir. Belirtilen eksiklikleri ve yazındaki önerileri dikkate alarak, bu araştırmada esasen NBD hesaplarına dayanan, fakat net bugünkü değer ölçütünün proje büyüklügü ve iskonto oranı sorunlarını bünyesinde barındırmayan İKO ölçütünü kullanmak tercih edilmiştir. Bilindiği gibi, İKO NBD'yi sıfır yapan iskonto oranıdır (İlter, 2001) ve birden fazla NBD hesabına dayalı iterasyonlarla hesaplanmaktadır. İKO hesabında Formül 2 kullanılmıştır.

$$
\dot{\mathrm{I}}_{r}=\dot{\mathrm{I}}_{1}+\frac{P V\left(\dot{\mathrm{I}}_{2}-\dot{\mathrm{I}}_{1}\right)}{P V+|N V|}
$$

Formül 2'de PV: sıfıra yakın pozitif net bugünkü değeri, NV: sıfıra yakın negatif net bugünkü değeri ifade ederken, $\dot{I}_{1}$ : PV'nin elde edildiği iskonto oranın1, $\dot{I}_{2}$ : NV'nin elde edildiği $\dot{I}_{1}^{\prime}$ den daha büyük ikinci iskonto oranını ifade etmektedir.

Bununla birlikte, yukarıda açıklandığı gibi, ENAT hem satın aldığ 1 hem de hazine arazilerinden teşvik 
kapsamında tahsis edilmiş arazilerde ağaçlandırma yapmıştır. $\mathrm{Bu}$ farklılık, yapılan yatırımın gelir ve gider ilişkisini değiştirmektedir. Arazi satın alımı, yatırımın ilk tesis masraflarına ek bir maliyet yüklerken, tahsis arazilerinde, arazi satın alımı yerine tahsis gideri söz konusudur. Diğer yandan, ENAT yatırımında bazı sahalara badem dikilerek, hem masraflar artırılmış hem ara gelir elde etme firsatı yaratılmıştır. $\mathrm{Bu}$ açıklamalardan da anlaşılabileceği gibi, bir yatırımı sadece, idare süresi, tür ve dikim aralığını dikkate alarak ekonomik açıdan değerlendirmek yeterli olmamaktadır. Üstelik satın aldığ1 araziyi, tıpkı diğer alanlardaki yatırımın hurda değeri gibi, yatırım sonunda satarak veya satmadan, girişimi sürdürmek de olanaklıdır. Bu nedenle, çalışmada, endüstriyel ağaçlandırmaların yapısıyla uyumu tartışılır badem yetiştiriciliği dışlanmış fakat "alternatif maliyetiyle birlikte, arazi maliyeti", diğer endüstriyel ağaçlandırmalarda ve farklı iktisadi özellikteki arazilerde de söz konusu olabileceği dikkate alınarak, kapsam içerisinde bırakılmıştır. $\mathrm{Bu}$ durum, araştırmada ENAT tarafından yapılmış tüm ağaçlandırmaları tek bir iç karlılık oranıyla açıklamak yerine "farklı durumlarda" ortaya çıkan İKO’ları belirlemeyi gerektirmiştir.

İdare süresi, ormancılıkta aynı yaşlı işletmeciliğin var olmaya başladığı on sekizinci yüzyıldan beri bilinen bir yönetsel değişkendir. Endüstriyel ağaçlandırmaların yapısı, aynı yaşlı işletmeciliğe uygundur. $\mathrm{Bu}$ nedenle, bir endüstriyel ağaçlandırma için en uygun idare süresinin ya kabulle kararlaştırılması ya da hesaplanarak bulunması gereklidir.

Odun çeşidine ve kalitesine bakılmaksızın genel ortalama odun artımının azami (en yüksek) olduğu yaşa dayanan idare süresine en yüksek odun hasılatı idare süresi denilmektedir. Gelir gider hesaplamaları yapılmadığı için ekonomik düşünceye yer vermeyen bir idare süresidir (Daşdemir, 2000). Gerçekten de, en yüksek odun hasılası idare süresinin karar ölçütü olarak kullanılması halinde, miktarı çok ama değeri az veya miktarı çok fakat net getirisi düşük seçeneklerin öne çıkabilmesi olasıdır. $\mathrm{Bu}$ nedenle, bu çalışmada, hasılat araştırmalarına dayalı olarak "en yüksek odun hasılası" idare süresi bulunmaya çalışılırken, yukarıda belirtilen yatırım seçeneklerinin, farklı idare süreleriyle birlikte değerlendirilmesiyle, İKO’yu maksimum yapan idare süresi araştırılmıştır. Nitekim OGM tarafından çıkartılarak ormanların planlanmasında yasal olarak uygulanmakta olan Orman Amenajman Yönetmeliğinde de idare süresinin belirlenmesinde iç karlılık oranı ya da net bugünkü değerin esas alınacağı öngörülmektedir (URL 3).

İKO hesapları 12-30 yaş aralığındaki, 19 ayrı ida- re süreleri için ayrı ayrı yapılmıştır. Yatırımcının sahibi olduğu ve başka hiçbir kullanıma tahsis edemediği, alternatif maliyeti bulunmayan, bu yatırım sonrası satışı mümkün olmayan bir arazide ağaçlandırmayı yapması durumu A senaryosu olarak adlandırılmış ve senaryo için 12-30 y1llık idare sürelerinin oluşturacağı İKO değerleri belirlenmiştir. Yatırımcının kendisine ait bir arazide ve yıllık $600 \mathrm{TL} /$ ha kira geliri elde edebileceği bir alanda yatırımı yapması durumu $B$ yatırım seçeneği olarak tanımlanırken, yatırımcının 22.518 TL/ha bedelle bir arazi satın alıp, ağaçlandıracağ1 ve ilk idare süresi sonunda arazisini satarak yat1rımdan çekileceği hali $C$ yatırım seçeneği olarak adlandırılmıştır. Satın alınan arazinin, ilk idare süresi sonunda satmadan yatırımcının elinde tutulması durumuysa $D$ yatırım seçeneği olarak ifade edilmiştir. D yatırım seçeneğinin sonraki yatırım maliyet ve getirilerinin dikkate alınması halinde "sonsuz" bir yaklaşım uygulamak gerekmekte, bu durumda da diğer seçeneklerle karşılaştırma olanağı bulunmamaktadır. Bu nedenle, D yatırım seçeneklerini $\mathrm{C}$ grubundan dönem sonu arazi satış gelirleriyle farklılaşan halleri temsil ettiği dikkate alınmalıdır. Devlet arazilerinden yapılan bedelsiz tahsislerle yatırımın yapılması, sadece arazi tahsis maliyetlerinin olması haline ise E yatırım seçeneği adı verilmiştir. Böylelikle 5 senaryo ve 19 farklı idare süresi olmak üzere, 95 farklı seçenek için ayrı ayrı iç karlılık oranları hesaplanmıştır.

İKO hesabında, ENAT'ın farklı yatırım yıllarında oluşmuş maliyet ve gelir kalemleri, oluşma yılları dikkate alınarak, 1 Ocak 2019 tarihi itibariyle reel değerlere dönüştürülmüştür. Dönüştürme işlemi TÜIK'in Parasal Değerleri Güncelleme aracı (URL 4) yardımıyla ve Tüketici Fiyat Endeksleri temel alınarak yapılmıştır. ENAT'ın 2005 yılında satın aldığ 1 arazilerin nominal fiyat1 $6.624 \mathrm{TL} /$ ha (reel 22.518 $\mathrm{TL} / \mathrm{ha}$ ) bulunurken, hazineden tahsis sağlamak üzere yaptığı masrafların ortalama nominal değeri 454,53 TL/ha (reel 1.590,70 TL/ha) olarak belirlenmiştir. Ağaçlandırma maliyetleri, arazi hazırlığı, fidan tedarik, dikim, koruma çalışmalarını kapsamaktadır. 2005-2017 dönemi yapılan ağaçlandırma çalışmalarının birim masrafları reel hale getirilerek, bu dönemde gerçekleşen ortalama ağaçlandırma gideri (10.334,5 TL/ha) hesaplanmıştır. Üretim maliyetleri kesim, bölmeden çıkarma ve alıcının fabrikasında teslim maliyetlerini kapsamaktadır. ENAT, 2017 ve 2018 yıllarında aralamalar yaparak bir üretim gerçekleştirmiştir. Bu yıllarda gerçekleşen reel üretim maliyetlerinin ortalaması 109,185 TL/ton olarak hesaplanmıştır. ENAT kestiği ürünleri taze ve hemen teslim sattığından, bu değer, 1 ton $0,86 \mathrm{~m}^{3}$ katsayısı temel alınarak (Kalıpsız, 1984) dönüştürülmüş ve aralama ve son kesim hasılasının 
alınacağ 1 yıllardaki üretim birim maliyeti $(93,90$ $\mathrm{TL} / \mathrm{m}^{3}$ ) olarak kullanılmıştır. Genel idare masrafla$\mathrm{r} 1$ ise, benzer çalışmalarda gelenekselleşmiş kabuller temel alınarak, ağaçlandırma giderinin \% $15^{\prime} \mathrm{i}$ (1.550.18 TL) olarak alınmıştır.

Gelir hesabının gerektirdiği üretim miktarları, yukarıda açıklandığ 1 gibi, yapılan hasılat araştırmalarından elde edilmiştir. 21 ve 22 yıllık idare sürelerinin hesaplarında, 20. Yaştaki aralama hasılası dışlanırken, diğer idare sürelerinde, 10 ve 20. Yaşlarda ara hasılat alınacağı öngörülmüştür. ENAT odun hammaddesini ton üzerinden satmıştır. 2015-2019 yılları arasında yıllık ortalama 382,37 ton odun ürünü satmış ve yıllık ortalama nominal 98.281,60 TL/yıl gelir elde etmiştir. Bu miktar ve gelirler dikkate alındığında odun ürününün reel birim satış fiyatı ortalaması $272,79 \mathrm{TL} / \mathrm{m}^{3}$ olarak hesaplanmıştır. Ton değerleri $\mathrm{m}^{3}$ 'e çevrilirken, maliyetlerde yapıldığı gibi, $1 \mathrm{~m}^{3}, 0,86$ ton denkliği kabul edilmiştir (Kalıpsız, 1984). ENAT yatırım süresi boyunca farklı dönemlerde \% 3,5 bileşik faiz oranıyla kamu kaynaklarından krediler kullanmıştır. Bu nedenle, satın alınan arazilerin satılmasını içeren senaryolarda idare süresi sonunda oluşacak arazi satış bedelinin, ormancılığa tahsis edilmiş bir arazi olduğundan bu sektörün ortalama karlılık oranı olarak kabul edilen yıllık \% 3 bileşik faizle hesaplanan baliğ değere erişeceği kabul edilmiştir.

\section{Bulgular}

\subsection{Gövde analizi bulguları}

Deneme alanlarını temsil edecek şekilde her deneme alanından alınan göğüs yüzeyi orta ağac1nın gövde analizi sonuçlarına dayalı olarak, yaşa bağlı kabuksuz göğüs çapı, boy ve kabuksuz gövde hacmi gelişimleri Şekil 2 de verilmiştir. Şekilden de görüleceği üzere, gövde analizi sonuçları; ağaçların tamamının boylarının 3. yaş ya da daha erken zamanda göğüs yüksekliğine eriştiğini, gögüs çaplarının, bonitet ve birim alandaki ağaç sayısına da bağlı olarak, hızla arttığını ve 12 yaş itibariyle 12-17 cm ye ulaştığını göstermektedir. Yine boylanmanın da benzer bir şekilde, özellikle bonitete bağlı olarak artarak, 12. yaşta 7-9 m. aralığında kümelendiği görülmektedir. Kabuksuz tek ağaç hacimlerinin de 12 . yaşta genelde $60-80 \mathrm{dm}^{3}$ civarında yoğunlaştığı ortaya çıkmaktadır.

\subsection{Deneme alanından elde edilen hasılat bulguları}

Ağaçlandırma yatırımlarının gerek odun hasılat1 (biyokütle) ve gerekse ekonomik açıdan analiz
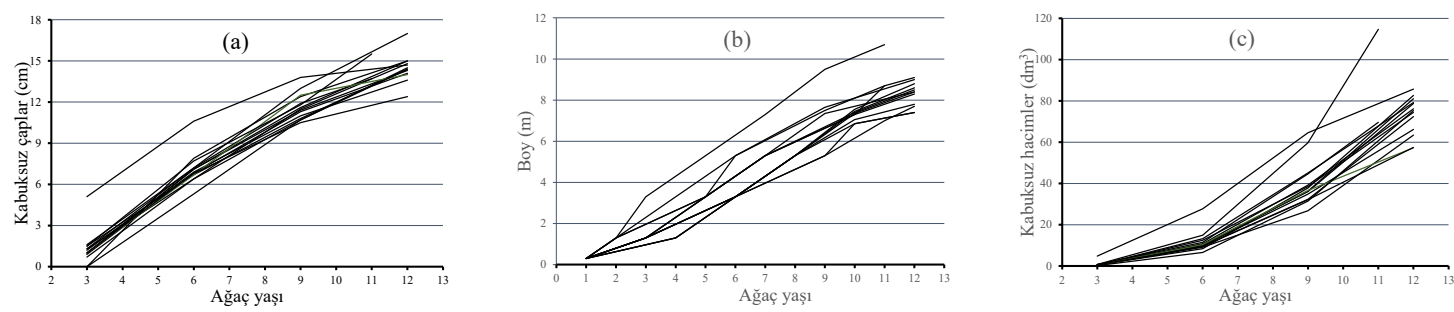

Şekil 2. Deneme alanı orta ağacına ilişkin çap (a), boy (b) ve hacim (c) gelişimleri.

Figure 2. Trends of diameter (a) length (b) and volume of the mean trees in the samplings

edilmesinde birim alandan elde edilecek odun ve para hasılatının dikkate alınması gerekir. Karacabey Sahilçamı ağaçlandırma sahasına ilişkin hektardaki hasılat değerleri Tablo 2 de verilmiştir. Ağaçlandırma çalışmasına ait kayıtlardan anlaşıldığı kadarıyla, dikim aralıkları $3 \times 1,5 \mathrm{~m}$ olarak kullanılmış, yani hektara 2222 adet fidan hesabı ile dikim yapılmıştır. Ancak 12. yaş itibariyle hektardaki ağaç sayısının genellikle daha az olduğu görülmektedir. Bunun temelde iki sebebinin olduğu kanaati oluşmuştur. Birincisi, dikim sırasında özellikle arazideki koşullara da bağlı olarak aralıklarda $3 \mathrm{~m}$ geçilmiş ve dolayısıyla ağaç başına düşen büyüme alanı buralarda artmıştır. İkincisi ise dikimi izleyen yıllarda meydana gelen fidan kayıpları nedeniyle bazı genişlemeler söz konusu olmuştur.
Deneme alanlarının alındığı 12 . yaşta aralama ile çıkartılan ağaç kütüklerinin de hesaba katılması sonucu hektardaki ağaç sayısının 1.300 ile 2.000 aralığında değiştiği görülmüştür. Diğer hasılat değerlerini etkileyen önemli bir parametre olan hektardaki ağaç sayısının değişimi, birim alandan elde edilecek gerek odun hasılatı ve gerekse para hasılatını da değiştirmektedir. Burada, ENAT özelinde mevcut duruma ilişkin elde edilen sonuçlar verilmiştir.

Deneme alanlarının bonitet endeksleri ve bonitet derecelerine bakıldığında Karacabey deneme alanlarının genelde iyi bonitetli alanlar olduğu görülmektedir. Ortalama artımın da 12. yaş itibariyle bonitetin iyi olduğu yerlerde $20 \mathrm{~m}^{3} / \mathrm{ha} / \mathrm{y} 1 \mathrm{l}$ değerini aştığı görülmektedir. 
Hektardaki ağaç serveti ve yıllık GOA'ların yaşa göre değişimleri Şekil 3a'da gösterilmiştir.
Şekil 3a'dan görüleceği üzere GOA 26. yaşta maksimum noktaya ulaşmaktadır.

Tablo 2. Deneme alanlarından elde edilen hasılat değerleri Table 2. Yield Findings of the samplings

\begin{tabular}{|c|c|c|c|c|c|c|c|c|c|c|c|c|}
\hline $\begin{array}{l}\text { Den. } \\
\text { Al. } \\
\text { No }\end{array}$ & Toplam & $\begin{array}{l}\text { Aralama } \\
\text { ile çıkan }\end{array}$ & Kalan & Yaş & $\begin{array}{c}\text { Aralama } \\
\text { Yaş1 }\end{array}$ & $\begin{array}{l}\text { Orta } \\
\text { Çap } \\
(\mathrm{cm})\end{array}$ & $\begin{array}{l}\text { Orta } \\
\text { Boy } \\
(\mathrm{m})\end{array}$ & $\begin{array}{l}\text { Üst } \\
\text { Boy } \\
(\mathrm{m})\end{array}$ & $\begin{array}{l}\text { Bonitet }^{1} \\
\text { Derecesi }\end{array}$ & $\begin{array}{c}\text { Bonitet }^{2} \\
\text { Endeksi } \\
\text { (m) }\end{array}$ & $\begin{array}{l}\text { Hacim } \\
\left(\mathrm{m}^{3} / \mathrm{ha}\right)\end{array}$ & $\begin{array}{c}\text { Ort. } \\
\text { Artım } \\
\text { (m3/y1l) }\end{array}$ \\
\hline 1 & 2000 & 767 & 1233 & 12 & 10 & 16,60 & 9 & 9,5 & I & 17,2 & 211,85 & 17,65 \\
\hline 2 & 1400 & 667 & 733 & 12 & 10 & 14,51 & 7,8 & 8,5 & II & 15,7 & 115,17 & 9,60 \\
\hline 3 & 1700 & 633 & 1067 & 12 & 10 & 15,53 & 8,4 & 8,8 & II & 16,1 & 158,17 & 13,18 \\
\hline 4 & 1700 & 733 & 967 & 12 & 10 & 17,55 & 8,8 & 9 & II & 16,5 & 183,69 & 15,31 \\
\hline 5 & 1467 & 533 & 933 & 12 & 10 & 15,85 & 8,6 & 8,9 & II & 16,3 & 142,41 & 11,87 \\
\hline 6 & 1667 & 633 & 1033 & 12 & 10 & 13,65 & 7,4 & 7,6 & II & 14,3 & 124,91 & 10,41 \\
\hline 7 & 1967 & 833 & 1133 & 12 & 10 & 15,85 & 8,3 & 9,5 & I & 17,2 & 183,74 & 15,31 \\
\hline 8 & 1367 & 400 & 967 & 12 & 10 & 15,59 & 7,7 & 8,5 & II & 15,7 & 121,62 & 10,13 \\
\hline 9 & 1433 & 633 & 800 & 12 & 10 & 16,78 & 8,5 & 9,1 & I & 16,6 & 143,50 & 11,96 \\
\hline 10 & 1600 & 800 & 800 & 12 & 11 & 16,38 & 9,1 & 9,5 & I & 17,2 & 168,16 & 14,01 \\
\hline 11 & 1400 & 0 & 1400 & 11 & - & 15,40 & 8,7 & 9,1 & I & 16,6 & 142,50 & 12,95 \\
\hline 12 & 1567 & 0 & 1567 & 12 & - & 14,75 & 7,4 & 8,3 & II & 15,4 & 124,57 & 10,38 \\
\hline 13 & 1600 & 0 & 1600 & 12 & - & 14,86 & 8,4 & 9 & II & 16,5 & 147,24 & 12,27 \\
\hline 14 & 1300 & 0 & 1300 & 12 & - & 15,92 & 8,2 & 8,5 & II & 15,7 & 131,84 & 10,99 \\
\hline 15 & 1600 & 733 & 867 & 11 & 9 & 19,16 & 10,7 & 11,5 & I & 22,6 & 218,40 & 19,85 \\
\hline
\end{tabular}

${ }^{1}$ : Özcan (2003) tarafından düzenlenen 3 lü bonitet tablosu kullanılmıştır.

2. 50 yaşındaki üst boy

Ağaç serveti ise artımın belli bir düzeyde olmasına mektedir (Şekil 3b). bağlı olarak 35. yaş itibariyle artmaya devam et-
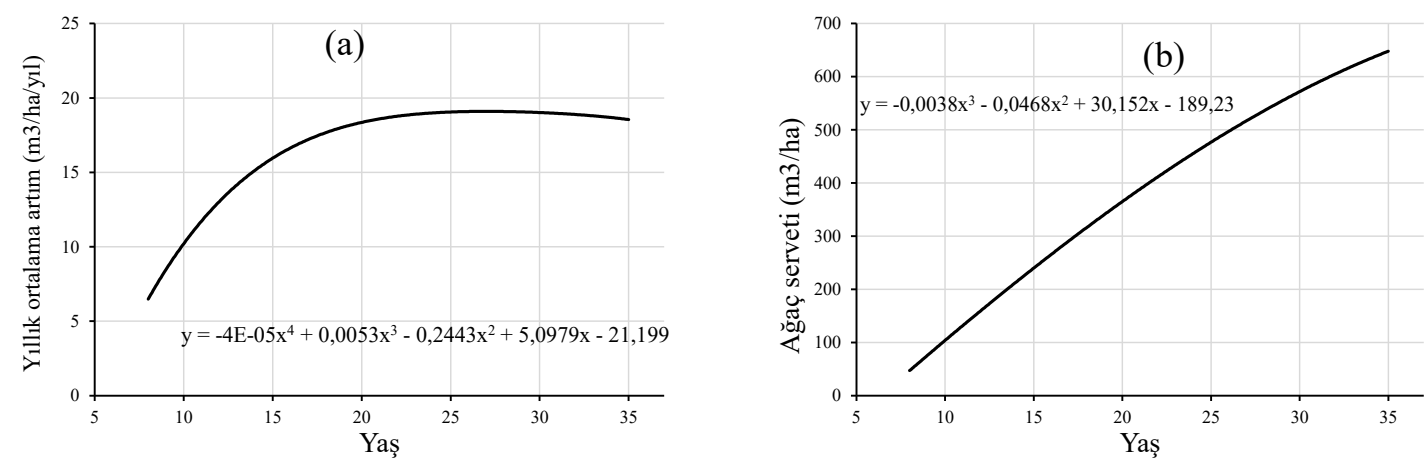

Şekil 3. ENAT-Karacabey ağaçlandırma sahasında yıllık genel ortalama artım (a) ve hektardaki ağaç servetinin (b) yaşa göre değişimi

Figure 3. The changes on mean annual increment (a) and growth per ha (b) according to different ages in the ENAT Karacabey afforestation areas.

\section{3. İç karlııı analizi bulguları}

farklı idare süreleri ve yatırım seçenekleri için hesaplanmış 95 ayrı İKO değeri Tablo 3’te gösterilmiştir. Tablo 3’ten görüldüğü gibi, en yüksek İKO yatırımcının alternatif maliyeti olmayan kendi arazisinde ve 15 yıllık İdare süresiyle yatırım yapması durumunda (A-15) ve \%12,263 olarak ortaya çıkmaktadır. Diğer koşullar sabitken, yatırımcının sahip olduğu araziyi aylık 50 TL/ha gibi, çok düşük de olsa kiraya verebilme durumunu gösteren senaryolardan (Tablo 3, sütun B) anlaşıldığ 1 gibi, 
Tablo 3: Farklı İdare Süreleri ve Yatırım Seçenekleri İçin Hesaplanmıș İç Karlılık Oranları (\%)

Table 3. Finding on İnternal Rate of Returns for Different Rotation ages and Investment Options (\%)

\begin{tabular}{cccccc}
\hline $\begin{array}{c}\text { İdare } \\
\text { süreleri } \\
(\text { Y11) }\end{array}$ & $\begin{array}{c}\text { A- Kendi Arazi- } \\
\text { sinde Alternatif } \\
\text { Maliyet Yok } \\
\text { (IKO \%) }\end{array}$ & $\begin{array}{c}\text { B- Kendi Arazisinde } \\
\text { Alternatif Maliyet } \\
\text { Var } \\
\text { (IKO \%) }\end{array}$ & $\begin{array}{c}\text { C- Arazi Satın } \\
\text { Alarak ve İlk İdare } \\
\text { Süresi Sonunda } \\
\text { Satarak } \\
\text { (IKO \%) }\end{array}$ & $\begin{array}{c}\text { D- Arazi Satın } \\
\text { Alarak ve İlk İdare } \\
\text { Süresi Sonunda } \\
\text { Satmadan } \\
\text { (İKO \%) }\end{array}$ & $\begin{array}{c}\text { E- Tahsis Edil- } \\
\text { miş Hazine } \\
\text { Arazilerinde } \\
\text { (IKO \%) }\end{array}$ \\
\hline 12 & 11,714 & 8,073 & 7,105 & 0,868 & 10,411 \\
13 & 12,075 & 8,530 & 7,315 & 1,908 & 10,854 \\
14 & 12,244 & 8,897 & 7,429 & 2,689 & 11,084 \\
15 & 12,263 & 9,817 & 7,472 & 3,256 & 11,172 \\
16 & 12,214 & 9,085 & 7,484 & 3,707 & 11,183 \\
17 & 12,079 & 9,053 & 7,451 & 4,007 & 11,102 \\
18 & 11,915 & 8,954 & 7,395 & 4,260 & 10,979 \\
19 & 11,734 & 8,838 & 7,320 & 4,436 & 10,839 \\
20 & 11,534 & 8,701 & 7,232 & 4,561 & 10,680 \\
21 & 11,305 & 8,530 & 7,126 & 4,633 & 10,491 \\
22 & 11,268 & 8,360 & 7,016 & 4,688 & 10,302 \\
23 & 11,103 & 8,324 & 6,975 & 4,751 & 10,276 \\
24 & 10,942 & 8,266 & 6,939 & 4,844 & 10,197 \\
25 & 10,791 & 8,116 & 6,861 & 4,857 & 10,041 \\
26 & 10,636 & 7,968 & 6,782 & 4,860 & 9,903 \\
27 & 10,474 & 7,835 & 6,699 & 4,850 & 9,766 \\
28 & 10,309 & 7,700 & 6,615 & 4,834 & 9,626 \\
29 & 10,138 & 7,558 & 6,528 & 4,808 & 9,482 \\
30 & 9,973 & 7,413 & 6,442 & 4,779 & 9,336 \\
\hline
\end{tabular}

alternatif maliyet tüm idare sürelerinde İKO’yu düşürmektedir. Arazinin alternatif maliyeti olması halinde en yüksek İKO yine 15 yaşta fakat \%9,817 olarak bulunmaktadır.

Yatırımcıların bir arazi sahibi olmamaları halinde, arazi satın alarak ve ilk idare süresi sonunda bu araziyi satmaları durumunda oluşan İKO değerleri Tablo 3'ün dördüncü sütununda ve $\mathrm{C}$ grubu seçenekler olarak gösterilmiştir. C grubu seçeneklerde de en yüksek İKO, 16 yaş için $(\% 7,484)$ hesaplanmıştır. İlk idare süresi sonunda arazi satılıyor olsa da arazi alım maliyetleri, A grubu seçeneklere göre İKO’yu daha aşağıya düşürürken, idare süresini de bir yıl uzatmıştır. Satın alınan arazinin ilk idare süresi sonunda satılmaması halinde, maksimum İKO $\%$ 4,860 ile 26. yaşta ortaya çıkmaktadır. Bir başka değişle, araziyi satmamak hem İKO’yu düşürmüş hem idare süresini uzatmıştır. Her ne kadar, hazineden tahsis yapılmış olsa da, diğer koşulları sabit bırakıp, tahsisi elde etmek için yapılan masraflar temel alınarak, hesaplamalar tekrarlandığında Tablo 3'ün E grubu bulguları ortaya çıkmaktadır. Tahsis seçenekleri arasında en yüksek İKO 16. yaş için

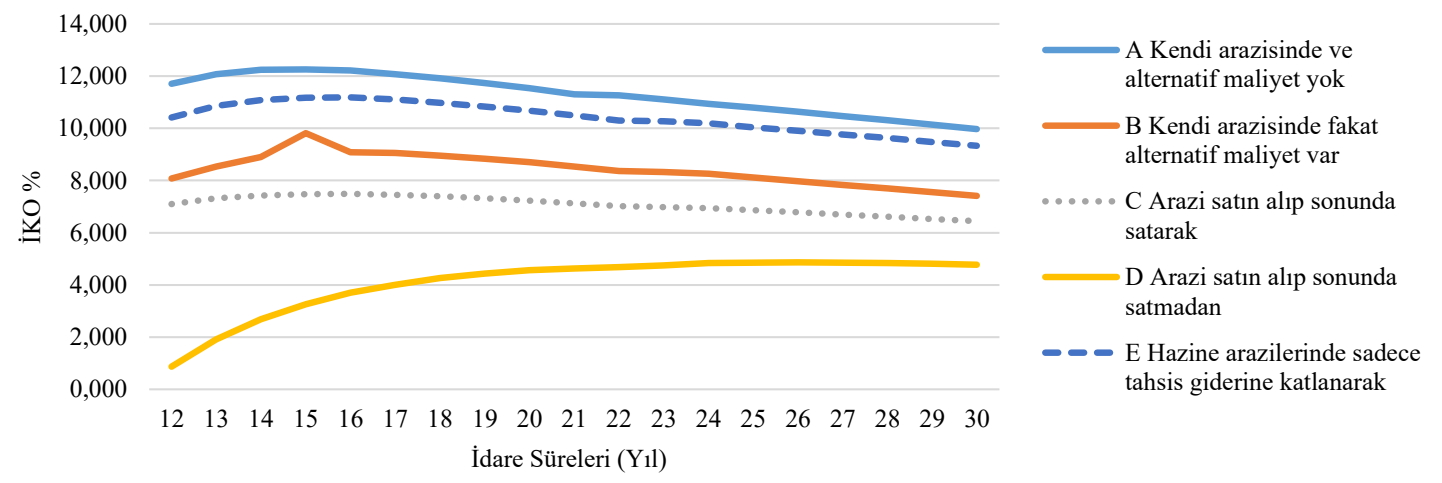

Şekil 4: İdare süresi değişimlerinin farklı senaryolarda gösterdiği yönelimler Figure 4: Trends of Different Scenarios According to Different Rotation Ages 
ve $\% 11,183$ olarak bulunmuştur.

İdare süresi 12 yaştan 30 yıla doğru değiştikçe, incelenen her senaryo grubunda gözlenen eğilimler Şekil 4'te gösterilmiştir.

Şekil 4’ten görüldüğü gibi, kendi arazilerinde ve hazineden tahsisli arazilerde yapılan ağaçlandırmalarda 15 yaşa kadar beklemek İKO’nı artırırken, bu yaştan sonraki bekleyişler karlılık üzerinde azaltıcı bir etki yapmaktadır. Arazinin alternatif maliyetinin olduğu sahipli araziler ile arazi satın alınıp ilk idare süresi sonunda satışın düşünüldüğü senaryolarda ise 16. yaşa kadar beklemek iyi bir yatırım kararı olarak görünürken, sonraki yaşlara karşılık gelen idare süreleri ekonomik görünmemektedir. Arazi satın alıp, idare süresi sonunda satışın düşünülmediği seçeneklerde, maksimum İKO, genel ortalama artımın en yüksek olduğu 26. yaşa kadar artmış sonra ise azalışa yönelmiştir.

\section{Tartışma, Sonuç ve Öneriler}

Türkiye'nin odun arz açığı sorunu altmışlı yıllarda tespit edilmiş, seksenli yıllarda kapsamlı çalışmalarla (Anonim, 1982) irdelenmişse de, halen çözüm bulunamamış (TOD, 2019a) bir sorundur. Endüstriyel ağaçlandırmalar halen en ciddi çözüm aracı olarak görünmekte fakat bir türlü artırılamamaktadır. Bu sonuç üzerinde, yatırım kararlarına temel olacak deneysel değerlere dayalı (ampirik) hasılat ve ekonomik analiz eksiklikleri etki yapmaktadır.

Sahilçamı ülkemizde hızlı gelişen yabancı orman ağaçları içinde en fazla kullanım alanına sahip, başarılı olmuş bir türdür ve iyi bonitetli sahalarda, 25 yaşında yılda $22 \mathrm{~m}^{3} /$ ha kadar artım yaptığ 1 görülmüştür (Özcan, 2003). Özellikle Batı Karadeniz ve Marmara Bölgelerinde sınırlı alanlarda da olsa ağaçlandırma potansiyeli mevcuttur.

Çalışmada ele alınan 15 deneme alanındaki hasılat ölçmelerine dayalı olarak düzenlenmiş Tablo 2'den de görüleceği üzere, özellikle bonitet endeksinin yüksek olduğu deneme alanlarında 12 yaş itibariyle ortalama artım $20 \mathrm{~m}^{3} /$ ha düzeyine yaklaşabilmektedir. Özcan (2003) tarafından ülkemizde daha önce yapılmış ve Sahilçamı ağaçlandırma alanlarına dayalı olarak hazırlanmış bonitet tablosu kullanılarak deneme alanlarında yapılan bonitet tespitlerinden, Karacabey Sahilçamı ağaçlandırmasının I. ve II. bonitetli alanlarda yapıldığ 1 ve bunun da birim alandaki hasılat değerlerine yansıdığ görülmektedir. Diğer yandan birim alandan elde edilen odun hasılatı bakımından değerlendirme yapıldığında Sahilçamına alternatif tür olan Kızılçamdan daha fazla, dişbudaktan ise daha az hasılat değerleri vermektedir (Özcan, 2003). Ancak ekolo- jik açıdan değerlendirildiğinde Sahilçamı için potansiyel ağaçlandırma sahası olabilen yerler büyük oranda Dişbudak için uygun alanlar olmamaktadır. Bu anlamda ENAT-Karacabey ağaçlandırma alanı gibi ekolojik koşulların uygun olduğu yerlerde Sahilçamı ağaçlandırmaları odun hasılatı verimi bakımından daha doğru bir seçenektir.

Çalışmadan elde edilen sonuçlarda dikkat çeken bir başka konu ise dikim aralıklarının, yani hektara dikilen ağaç sayısının yıllık ortalama artım üzerine etkisidir. 1 ve 10 nolu deneme alanlar1nın bonitet endeksleri eşit olmasına rağmen, hektardaki ağaç sayısına bağlı olarak yıllık ortalama artımları arasında 12 . yaş itibariyle $3,5 \mathrm{~m}^{3} /$ ha dan fazla fark oluşmuştur. Bu fark daha dar dikim aralıkları kullanılarak daha da artırılabilir görünmektedir. Benzer şekilde 4 ve 11 nolu deneme alanları yaklaşık aynı bonitet endeksine sahip olmasına rağmen, başlangıçtaki ağaç sayısına bağlı olarak yıllık ortalama artımları arasında fark oluşmuştur. Çalışmada elde edilen bu bulgu mevcut literatür bilgileriyle uyumludur. Nitekim konuya birim alandan alınacak gövde hacmi olarak bakıldığında, kısa idare süreleri için dar aralık mesafenin daha avantajlı olduğunu gösteren çok sayıda çalışma vardır. Örneğin, Amateis ve Burkhart (2012) Taeda çamında (Pinus taeda L.) 1,22x1,22 m den başlayarak 3,65x3,65 m ye kadar değişen dört değişik aralık-mesafedeki kare dikim ile 1,22x1,83 m den başlayarak 3,65x2,44 m ye kadar değişen yine dört değişik aralık-mesafedeki dikdörtgen dikimi hektardaki odun üretimi açısından incelemiştir. 13 yaşı için yaptıkları değerlendirmede en yüksek hacmin, 1,22x1,22 m aralık mesafe ile yapılan dikimden elde edildiğini hesaplamışlar ve endüstriyel odun üretiminin amaçlanması durumunda dar dikim aralıkları ve kısa idare süresinin tercih edilmesini önermişlerdir. Kısa idare süresi dar dikim aralığının birim alandan daha fazla odun ürünü elde etme avantajını sağlamakla kalmayıp aynı zamanda paranın zaman değerini dikkate alan IKO gibi ekonomik değerlendirme kriterlerinin daha yüksek olarak elde edilmesini de sağlayacaktır.

Erkan ve Aydın (2016) tarafından kızılçamda yapılan bir çalışmada, endüstriyel odun üretimi amaçlı ve kısa idare süreli ağaçlandırma çalışmalarında, tek yönlü makinalı bakıma da izin vermesini dikkate alarak, ülkemizde kızılçam ile yapılacak endüstriyel ağaçlandırma çalışmaları için $3 \times 1 \mathrm{~m}$ veya $3 \times 1,5 \mathrm{~m}$ dikim aralıklarının kullanılabileceğini vurgulamışlardır. Aynı çalışmada, 12. yaş için yaptıkları değerlendirmede en yüksek gövde hacmini en düşük aralık mesafe $\left(2 \mathrm{~m}^{2} /\right.$ ağaç, büyüme alanı) için hesaplamışlardır. Yine, Usta (1991), Güney Anadolu Bölgesi’ndeki Kızılçam 
ağaçlandırmalarında ağaç başına 2,0 $\mathrm{m}^{2} ; 3,0 \mathrm{~m}^{2}$; $4,5 \mathrm{~m}^{2} ; 6,0 \mathrm{~m}^{2} ; 9,0 \mathrm{~m}^{2}$ ve $25,0 \mathrm{~m}^{2}$ olmak üzere, 6 değişik büyüme alanı (dikim aralıkları) için hasılat ögelerini hesaplamış ve en yüksek değerleri en dar aralık olan 2,0 $\mathrm{m}^{2}$ büyüme alanı için bulmuştur.

Ayrıca dar dikim aralıkları yatırım maliyetlerini kısmen olumsuz etkilemekle birlikte doğal dal budanmasının daha hızlı olması ve hacmin daha yüksek oranda gövde odununda birikmesi ve kaliteli gövde odunu üretimi gibi avantajlar sağlamaktadır (Kerr, 2003; Stape ve Binkley, 2010).

Ağaçlandırmalarda birim alandaki hasılat verimi hesaplanırken, 3x1 m dikim aralığ 1 , dikim şekline bakmaksızın ağaç başına $3 \mathrm{~m}^{2}$ olarak değerlendirilebilir. Nitekim yapılan çalışmalar göstermiştir ki, dikdörtgen dikimlerde aralık:mesafe oranı 1/3'ü geçmediği sürece, ağaçların alan kullanımı bakımından dikdörtgen dikim ile kare dikim arasinda fark yoktur (Zhang ve ark., 1996; Sharma ve ark., 2002; Amateis ve ark., 2004).

Ülkemizde yapılan Sahilçamı ağaçlandırmalarını ekonomik açıdan analiz eden çalışmalar da bulunmaktadır. Tunçtaner ve ark., (2007) Bartın Karaçaydere bölgesinde yapılan Sahilçamı ağaçlandırmalarını hem hasılat hem ekonomik açıdan değerlendirmiştir. Bu çalışmanın ekonomik analizlerinde, ağaçlandırma yapılacak arazide bozuk bir orman olduğu ve bu ormandan bir odun hasılası alınacağı $\left(9,6 \mathrm{~m}^{3} / \mathrm{ha}\right)$ varsayılmış, arazi için bir maliyet hesaplanmadan, iyi ve kötü bonitetli yerlerde makinalı ve emek yoğun yapılacak ağaçlandırmalar için ayrı ayrı İKO hesaplanmıştır. 25 yıllık idare süresi için iyi bonitetli yerlerde \%13,09 İKO hesaplanmışken, kötü bonitetli yerlerde \%5,22 İKO bulunmuştur. Tunçtaner ve ark., (2007) \%13,09 şeklindeki bulguları, bu çalışmanın elde ettiği maksimum İKO değerinden $(\% 12,263)$ daha yüksektir. $\mathrm{Bu}$ durumun nedenleri incelendiğinde, her iki çalışmanın ağaçlandırma birim masrafları arasındaki yüksek fark dikkat çekmektedir. Tunçtaner ve ark., (2007) bugünün fiyatlarıyla 5.555,05 TL/ha ağaçlandırma giderine göre İKO hesaplamışken, bu çalışmada 10.334,50 TL/ ha ağaçlandırma gideri (\%53 fazla) kullanılmıştır. Gerçekten de, diğer kalemler sabit tutulurken, bu çalışmanın ağaçlandırma gideri aynı oranda (\%53) düşürülerek, İKO yeniden hesaplandığında, A15 numaralı seçeneğinin İKO’nının \%12,263'den \%18,001'e yükseldiği görülmektedir. Diğer yandan, Tunçtaner ve ark., (2007) hesaplamalarında, bu çalışmada olduğu gibi \%15 oranında genel idare gideri kullanılmışsa da, daha düşük bir idare masrafına dayalı bir hesaplama yapıldı $\breve{g}_{1}$, bunun da daha yüksek İKO sonucu verebileceği görülmüştür. Ayrıca, Tunçtaner ve ark., daha yatırımın ilk yılından 9,6 $\mathrm{m}^{3} /$ ha odun hasılasını ağaçlandırma alanını hazırlarken elde edeceklerini, bir başka deyişle, bir gelir oluşacağını varsaymışken, bu çalışmada sadece aralama ve son hasıla gelirleri yer almıştır. Bütün bunlara rağmen, ENAT Karacabey ağaçlandırmasında, Bartın Karaçay bölgesinin iyi bonitetli yetişme ortamına yakın ve hatta üstün bir İKO ürettiği görülmektedir.

Yetişme ortamının karlılık üzerine etkisini dikkate alarak, esasen bu araştırma sonuçlarını Balıkesir bölgesi çalışma sonuçlarıyla karşılaştırmak daha yararlıdır. Ancak, aynı yörede Sahilçamı ile yapılmış başka hasılat ve İKO analizleri bulunmamaktadır. Buna karşılık, yöreye çok yakın olan Manyas’taki kızılçam ağaçlandırmalarını Özel ve ark., (2017) analiz edilmiştir. Özel ve ark., (2017) Manyas yöresi Kızılçam ağaçlandırmalarının 30 yıllık idare süresinde, kötü bonitetli yerlerde $\% 3,70$, iyilerde ise 7,47 İKO üreteceğini ifade etmektedir. Özel ve ark.,nın (2017) bulgularıyla, bu araştırma sonuçları karşılaştırıldığında, Sahilçamının arazi maliyetinin olmadığı tüm idare sürelerinde (A grubu) kızılçamdan daha yüksek İKO üretebildiği, fakat arazinin alternatif maliyeti ile tedarik maliyetinin ortaya çıkmasıyla birlikte, bu üstünlüğünü kaybettiği görülmektedir. Bununla birlikte, Özel ve ark., (2017) hesaplarında kullanılan ağaçlandırma giderinin reel değerinin (7.934,16 TL/ha), bu çalışmada Sahilçamı için kullanılan değerden daha düşük olduğu gözden uzak tutulmamalıdır.

Pek çok noktada Kızılçam ile Sahilçamı'nın alternatif olarak görüldüğü açıktır. Daşdemir ve ark., (2019), Şanlıurfa'da yapılan Kızılçam ağaçlandırmalarında, bonitete göre, \%1,46 ve 2,19 şeklinde iki ayrı İKO hesaplamışken, Erkan ve ark. (2002), geleneksel yöntemlerle yapılmış kızılçam ağaçlandırmaları için hazırlanmış hasılat tablosu değerlerini kullanarak yaptıkları ekonomik analizler sonucunda İKO'nı kötü bonitetli yerler için $\% 4,48$, iyi bonitetli yerler için de $\% 7,64$ olarak hesaplamışlardır. Endüstriyel nitelikli ağaçlandırmalar için hesaplanacak bu IKO değerlerinin yükseleceği ortadadır. Ancak bu sonuçlara göre, ENAT'ın Karacabey'deki Sahilçamı ağaçlandırmaları genelde Kızılçamlardan daha fazla İKO üretebilmiştir. Bununla birlikte Kızılçam ve Sahilçamı ile yapılacak endüstriyel ağaçlandırmalar için potansiyel alanların kesiştiği bölgelerin sınırlı (Marmara ve Trakya Bölgesi) olduğu düşünüldüğünde her iki tür için ayrı ayrı fizibilite çalışmalarının yapılması daha isabetli görülmektedir.

$\mathrm{Bu}$ çalışmada, kendi arazisinde alternatif maliyet var ve yok veya satın alınan arazilerde ve dönem sonu satış yaparak veya yapmadan veya tahsis arazilerinde bir tahsis maliyetine katlanarak yapılan 
ağaçlandırma yatırımları için hesaplanmış İKO değerleri, arazi maliyetinin İKO üzerindeki güçlü etkisini ortaya koymaktadır. Sahilçamı veya başka türlerle yapılacak ağaçlandırmalarda, yatırımcının arazi bulma giderleri arttıkça, bu gibi yatırımlara girmekten uzaklaşacağı kesin görünmektedir. Ağaçlandırma yapılan arazi üzerinde, çok küçük gelirler de getirse, tüm alternatif yatırım alanlarının, ağaçlandırmalara ciddi rakip olacağı ortaya çıkmaktadır. Üstelik satın alınan arazinin sadece bir idare süresi değil, sonraki idare sürelerinde de ağaçlandırmada kullanılması, bir başka değişle, sonraki ağaçlandırmalarda arazi maliyetinin düşecek olması, karlılık üzerinde kayda değer olumlu etkiler yapamamaktadır. Bu nedenle, teşvik çalışmalarında arazi temini özel bir önem taşımalıdır.

Benzer sonuç ağaçlandırma giderlerinde de görülmektedir. 15 yaş için ağaçlandırma giderinin sadece $\% 10$ düşmesi (10.335,5'den 9.301,05 TL/ha) hesaplanan İKO'yu \%12,263'de \%13,075'e yükseltmektedir. Bir başka deyişle, ağaçlandırma giderlerini $\% 10$ düşüren bir teşvik aracının 15 yıllık bir idare süresinde İKO’yu \%6,63 artıracağ1 ortaya çıkmaktadır.

Ağaçlandırma gideri yanında, idare masrafları, hasat giderleri ile ürün fiyatlarının da $\mathrm{iKO}$ üzerinde etkisini ortaya koymak için duyarlılık analizleri yapmak, teşvik araçlarını tartışmak için yararlıdır. İKO’yu etkileyen diğer değişkenler sabitken, genel idare giderlerinin \%10 azalması halinde, İKO $\% 12,263$ 'den $\% 12,384$ düzeyine $(+\% 0,99)$ yükselmektedir. Aralama ve son kesim masrafları \%10 azaltılıp, diğer değişkenler sabit tutulduğunda ise İKO \%12,263'den 12,725 'e (+ \%3,77) yükselmektedir. Diğer yandan özellikle taşıma masraflarının azaltılmasına yönelik alınacak tedbirler de işletmenin ekonomik başarısını etkileyen faktörlerdendir. $\mathrm{Bu}$ anlamda, lif - yonga levha sanayi için gereken yongalamanın mahallinde yapılması ve endüstriyel plantasyon ile orman endüstri fabrikalarının kuruluş yerleri arasındaki mesafenin kısaltılmas1 konuları uzun yıllardan beri üzerinde durulan (Anonim, 1982), ancak halen daha gündemde olan konulardır. Bu sonuçlara göre, yatırımcıları idare masraflarını düşürecek teşvik araçları ile (personel vergi avantaj1, demirbaş amortisman desteği ..vb.) desteklemeye göre, hasat masraflarını düşürecek araçlarla desteklemek (yakıt desteği, personel vergi avantajı, yol ve altyapı desteği, ..vb.) karlılı̆̆ daha fazla olumlu etkileyecektir.

Şüphesiz yatırımın karlılığı giderler kadar gelirlerden de etkilenmektedir. Ürünlerin reel değerleri kullanılarak yapılan bu araştırma aslında, 2005-2019 dönemi için geçerli nispi (göreli) fiyatlara dayalı bir analizdir. Oysa zamanla kıtlaşan veya bollaşan mallar, nispi fiyat dengelerini değiştirmekte, fiyat endekslerine dayalı düzeltmeler bu değişimleri yansıtmakta tam başarılı olamamaktadır. Bu nedenle, diğer koşullar sabitken, odun hammaddesi birim değerinin gelecek dönemlerde $\% 10$ artacağı varsayılarak hesaplamalar yenilendiğinde, İKO \%12,263'den $\% 13,523$ 'e $(\% 10,27)$ yükselmektedir. Bu nedenle, ağaçlandırma yatırımlarının sadece bugünkü duruma göre yapılmış karlılık analizlerini dikkate almamak, gelecek dönem odun piyasasının durumuna yönelik güçlü eğilimleri de göz önünde bulundurmak gereklidir. Yeşil ekonomi anlayışının gelişmesinin odun hammaddesinin nispi değerini artırması beklenmelidir. Bu durumu teşvik araçları açısından da göz önünde bulundurmak zorunludur. Giderleri azaltıcı teşviklere göre, gelirin karlılık üzerinde daha fazla etkide bulunduğu ortadadır. $\mathrm{Bu}$ nedenle, satılan odun ürünü üzerinden gelir vergisi avantajları sağlamak, alım garantileri vermek, şeklinde araçların ağaçlandırma yatırımlarında gündeme gelmesi gereklidir.

Ülkemiz odun hammaddesi arz açı̆̆ının kapatılmasında çözüm yollarından birisi olarak önerilen, orman endüstri kuruluşlarının diğer ülkelerde olduğu gibi kendi ihtiyaçlarını karşılayacak ağaçlandırma yatırımları yapmaları düşünüldüğünde ekonomik boyut önem kazanmaktadır. Nitekim bu çalışma da göstermiştir ki, alternatif maliyetleriyle birlikte, arazi masraflar1 sorunu çözülmedikçe problem devam edecektir. Sorunun etkin bir şekilde çözümü için, orman endüstrisinde yaratacakları katma değeri de dikkate alarak bu kuruluşlara arazi tahsisleri, vergi muafiyetleri ve ürün destekleri sağlanmalıdır. Ayrıca, üretilen odun hammaddesine ek olarak, tutulan karbonun satışını sağlayarak gelirlerin artırılması önemli bir teşvik aracı olacaktır. Yatırım kararı ülke ekonomisinden etkilenen bir karardır. Bu çalışmada hesaplanan İKO değerleri göstermektedir $\mathrm{ki}$, yapılan yatırım ormancılık için kabul edilen \%3’lük sektörel karlılık oranının üstünde bir ekonomik sonuç üretmektedir. Ancak, ağaçlandırma yatırımlarına verilen uzun dönemli kredilerin faiz oranlarının \%10'ların altına düşmesi gerektiği görülmektedir. Diğer yandan, girişimcilerin ağaçlandırmaya alternatif yatırımlardan elde edecekleri karlılık düzeyinin \%10'ların altına doğru düşmesinin, ağaçlandırma yatırımlarına yönelimi destekleyeceği açıktır.

\section{Teşekkür}

$\mathrm{Bu}$ araştırmanın yapılabilmesi için gerekli verileri ve araştırma ortamını sağlayan ENAT A. Ş. Genel Müdürü Orman Yüksek Mühendisi Fikret 
KOÇAK'a ve Karacabey'deki firma çalışanlarına teşekkür ederiz.

\section{Kaynaklar}

Amateis R. L., Burkhart H., E., 2012. Rotation-age results from a Loblolly Pine spacing trial. Southern Journal of Applied Forestry, 36: 11-18.

Amateis, R.L., Radtke, P.J. and Hansen, G.D., 2004. The effect of spacing rectangularity on stem quality in loblolly pine plantations, Can. J. For. Res. 34:498-501

Anonim 1982. 21-26 Eylül 1981 Tarihleri Arasında İzmit Kefken'de Yapılan “Türkiye'de Hızlı Gelişen Türler ile Endüstryel Ağaçlandırmalar” Simpozyumu ve Ekskürsiyonu Değerlendirme Raporu. Ankara.

Balçık, B., 2003. Yatırım Projelerinin Hazırlanması ve Değerlendirilmesi, Nobel yayınc1lık, ISBN: 975-591460-9, 171 sayfa.

Birler, A. S., Yüksel, Y., Diner, A., 1989. I-214 Melez Kavak Ağaçlandırma Ekonomisi Kavak ve Hızlı Gelişen Orman Ağaçları Araştırma Enstitüsü 1989-1, Teknik Bülten No: 145, 196 sayfa, İzmit.

Birler, A.S., 2009. Endüstriyel Orman Ağaçlandırmalar1, Düzce Orman Fakültesi Yayın No:4, İzmit.

Daşdemir, 2000. İdare süresinin belirlenmesi, İç Anadolu Ormancılık Araştırma Enstitüsü Yayınları, Dergi serisi, Orman Bakanlığı yayın no 121.

Daşdemir, İ., Özel, H. B., Kaya, H., 2019. Technical and economical evaluations of Calabrian pine (Pinus brutia Ten.) semi-arid plantations in the Şanliurfa-Harran Plain of Turkey, Applied Ecology and Environmental Research · January 2019 DOI: 10.15666/aeer/1702_17571772

Daşdemir, İ., Şahin, A., 2002. Bartın Yöresi Ağaçlandırma Alternatiflerinin Ekonomik Değerlendirilmesi, ZKÜ Bartın Orman Fakültesi Dergisi Y11: 2002 Cilt:4 Sayı:4

Diner, A., Koçer S., 1999. I 214 Melez Kavak Ağaçlandırmalarında Ara Tarımın Kavakçılık Ekonomisine Etkileri, OB yayın No: 109, Müdürlük Yayın No: 228, ISBN: 1300-395X, 187 sayfa, İzmit.

Dow, T. M., Shaw, R., 1966. Ağaçlandırma Ekonomisi, Türkiye Orman Mühendisliği Birinci Teknik Kongresi, Cilt 2, s. 443-450.

Eraslan, İ. 1983. Hızlı Büyüyen Ağaç Türlerinin Önemi, Tanımı ve Türkiye'de Bu Türlerle Kurulacak Plantasyonların Potansiyel Üretim Kapasitesi, İ.Ü. Orman Fakültesi Dergisi Seri B, Say1 2 Cilt 33, s.1-27. İstanbul

Erkan, N., Uzun, E., Baş, M. N. 2002. Odun Üretim Amaçlı Kızılçam Ağaçlandırmalarında Ekonomik Analizler. Batı Akdeniz Ormancılık Araştırma Müdürlüğü, Teknik Bülten No: 17, Müdürlük Yayın No: 19, Antalya, 41 s.

Erkan, N.; Aydın, A.C., 2016. Effects of spacing on early growth rate and carbon sequestration in Pinus brutia Ten. plantations. Forest Systems, Volume 25 (2):1-11,

\section{http://dx.doi.org/10.5424/fs/2016252-09290}

İlter, E., 2001. Yatırım Projelerinin Hazırlanması, Değerlendirilmesi ve İzlenmesi, 305 sayfa. ISBN: 97596967-1-1. Bolu.

İlter, E., Ok, K., 2012. Ormanc1lik ve Orman Endüstrsinde Pazarlama İlkeleri ve Yönetimi, III: Baskı, ISBN: 978-975-96967-5-7. 422. Sayfa. Ankara.

Kalıpsız, A., 1984. Dendrometri, İ.Ü. Orman Fakültesi yayın no: 354 , İstanbul

Kerr, G., 2003. Effects of spacing on the early growth of planted Fraxinus excelcior L., Can. J. For. Res. 33:1196-1207

Koçer, S., 1999. Ülkemiz Kavakçılığının Geliştirilmesinde Yeni Finansman Olanakları, OB yayın No: 119, Müdürlük Yayın No: 229, ISBN: 1300-395 X, 280 sayfa, İzmit.

OGM, 2013. Endüstriyel Ağaçlandırma Çalışmaları Eylem Planı (2013-2017), Orman Genel Müdürlüğü Yayını, Ankara

OGM, 2019. Orman İstatistikleri, İşletme Pazarlama Daire Başkanlığı, Ankara (yayımlanmamış)

Özcan, G., 2003. Sahilçamı (Pinus pinaster Ait.) Ağaçlandırmalarında Artım ve Büyüme. Kavak ve Hızlı Gelişen Orman Ağaçları Araştırma Enstitüsü, Teknik Bülten No:195, İzmit.

Özel, H., B., Daşdemir, İ., Üzgün, S., 2017. BalıkesirManyas Yöresi Kızılçam (Pinusbrutia Ten.) Ağaçlandırmalarının Teknik Ve Ekonomik Analizi, 2023'e Doğru 4. Doğa ve Ormancılık Sempozyumu, ISBN: 978-60501-1108-8. Antalya.

Scharma, M., Burkhart, H.E., and Amateis, R.L. 2002. Spacing rectangularity effect on the growth of lablolly pine plantations. Can. J. For. Res. 32: 1451-1459

Stape, J.L., Binkley, D. 2010. Insights from full-rotation Nelder spacing trials with Eucalyptus in Sao Paulo, Brasil. Southern Forests 72(2):91-98

TOD, 2019. Türkiye Ormanc1lığ1: 2019, ISBN: 978-97593478-4-0, 164+20 sayfa, Kuban Matbaacıl1k Yayınc1lik, Ankara.

TOD, 2019a. Orman Genel Müdürlüğünce Uygulanmakta Olan "Endüstriyel Ağaçlandırma Çalışmaları Eylem Planı" Üzerine Değerlendirmeler ve Öneriler, https://www.ormancilardernegi.org/icerik_detay. asp?Icerik=1634 (Erişim tarihi: 15 Ağustos 2019)

Tunçtaner, K., 2007. Orman Genetiği ve Ağaç Islahı, Türkiye Ormancılar Derneği, Eğitim Dairesi 4, Ankara.

Tunçtaner, K., Daşdemir, İ., Ertekin, M., Özel, H., B., 2007. Batı Karadeniz Bölgesi Sahilçamı (Pinus Pinaster Aiton) Ağaçlandırmalarında Büyümeye İlişkin Teknik Ve Ekonomik Değerlendirmeler (Bartın-Karaçaydere Örnek Çalışması), TÜBİTAK TOVAG Proje no. 3113. Proje Sonuç Raporu. 89. Sayfa.

Tunçtaner, K., Tulukçu, M., Toplu, F. 1988. Sahil Çamı 
(Pinus pinaster Ait.) Orijinlerinin Morfogenetik Özellikleri ve Büyüme Performansları Üzerine Araştırmalar, Kavak ve Hızlı Gelişen Orman Ağaçları Araştırma Enstitüsü, Teknik Bülten No:144, İzmit

URL 1. Orman istatistikleri, https://www.ogm.gov.tr/ ekutuphane /Sayfalar/ Istatistikler.aspx? (Erişim tarihi: 22 Ağustos 2019)

URL 2. Özel Ağaçlandırma Tamimi (Tamim No:6912), $\quad$ https://www.ogm.gov.tr/ekutuphane/Tamimler/6912\%20-\%20\%C3\%96ze1\%20 A\%C4\%9Fa\%C3\%A7land\%C4\%B1rma\%20Tamimi. pdf (Erişim tarihi: 18 Temmuz 2019)

URL 3. Orman Amenajman Yönetmeliği, https://www.
ogm.gov.tr/ekutuphane/Yonetmelikler/Orman\%20Amenajman\%20Y\%C3\%B6netmeli\%C4\%9Fi.pdf (Erişim tarihi: 14 Temmuz 2019)

URL 4. TÜİK Parasal Değerleri Güncelleme Aracı https://biruni.tuik.gov.tr/medas/donusum hesap.zul, Erişim tarihi: 22 Ağustos 2019)

Usta, H. Z., 1991. Kızılçam (Pinus brutia Ten.) Ağaçlandırmalarında Hasılat Araştırmaları, Ormancılık Araștırma Enstitüsü Yayınları, Teknik Bülten No: 219, ANTALYA

Zhang, S., Burkhart. H.E., and Amateis, R.L. 1996. Modeling individual tree growth for juvenile loblolly pine plantations, For. Ecol. Manage. 89:157-172. 